P2048

\title{
就労女性における女性特有の症状と医療アクセスに 関する研究
}

\author{
豊川 智之 1 、小林 廉毅 ${ }^{1}$ 、笠原 说夫 ${ }^{2}$ 、高橋 真理 $^{3}$ \\ ${ }^{1}$ 東京大学 大学院 医学系研究科 公衆衛生学教室、 ${ }^{2} \mathrm{~J} \mathrm{R}$ 東日本健康推進センター、 \\ 3 北里大学 看護学部
}

【目的】就労女性の健康問題と医療へのアクセスに関する基礎資料として、一般健常女性における「最も気に なる症状」の割合(有訴割合)及び、産婦人科来院患者における症状の割合(有症割合)について就労の有無によ る差を検討した。【方法】一般女性を対象とした調查は、平成 14 年 11 月から平成 15 年 3 月までに、8 都道 恷県の一般企業女性社員と通信教育受講生、女子大学生、幼稚園児の母親を対象に実施した。来院女性を対 象とした調查は、平成 13 年 10 月から、平成 13 年 12 月まで、 5 大学病院、14一般病院、12 診療所の産婦人 科に来院した初診女性患者を対象に実施した。分析対象症状は産婦人科関連の症状で、来院女性及び一般女 性において共通におこりうる、生理痛及び生理の量が多い、生理不順、生理前に具合が悪い、生理と生理の 間の痛み、不正出血、おりもの及び外陰部のかゆみ及び痛み及びできもの（以下、おりもの外陰関連症状）、 更年期障害（顔がほてる、汗をかきやすい含む）、乳房のしこり、乳房のはり、赤ちゃんができないの 10 症 状であった。【結果】一般女性のうち「主婦、学生、その他」に該当する者は 662 名(30.1\%)で平均年齢は $28.6 \pm 10.9$ 歳、就労女性は 1535 名(69.9\%)で平均年齢は $36.1 \pm 10.1$ 歳あった。来院女性において「主婦、学生、 その他」に該当する者は 567 名(39.1\%)で平均年㱓は $38.9 \pm 15.3$ 歳、就労女性は 884 名(60.9\%)で $37.4 \pm 11.9$ 歳であった。一般女性における有訴割合をみると（表)、不正出血や更年期障害、赤ちゃんができないとい った症状が就労女性に多いことが示された。他方、生理不順及び無月経は就労女性に少ないことが示された。 来院女性における有症割合をみると（表）、生理痛及び生理の量が多いが、就労女性に多いことが示された。 他方、不正出血、おりもの外陰関連症状、更年期障害などは、来院患者において非就労女性が多い傾向が見 られた。生理不順及び無月経、赤ちゃんができない、乳房のしこりなどは就労による差が小さかった。【考察 とまとめ】就労女性と非就労女性との間で有症割合と有訴割合に差がみられた。重症疾患の可能性が含まれ る不正出血は、一般の就労女性に多い症状だが、来院する就労女性には少なかった。女性特有の症状に対応 する環境整備を通じて、就労女性の医療へのアクセスを確保する必要性が考えられた。

\begin{tabular}{|c|c|c|c|c|c|c|}
\hline & & 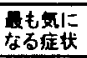 & 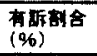 & & 棈院青 & $\begin{array}{l}\text { 有痓都会 } \\
(96)\end{array}$ \\
\hline \multirow[t]{2}{*}{ 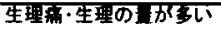 } & 非睯学 & 11 & 6.9 & 翡原労 & 38 & 12.4 \\
\hline & 乾労 & 27 & 7.9 & 就労 & 83 & 18.9 \\
\hline \multirow{2}{*}{ 生理不明-每月経 } & 非轨学 & 49 & 30.6 & 非勃労 & 46 & 15.0 \\
\hline & 就労 & 77 & 22.4 & 就労 & 70 & 15.9 \\
\hline \multirow{2}{*}{ 生理と生理の間の期み } & 非就労 & 4 & 2.5 & 非就労 & 5 & 1.6 \\
\hline & 就労 & 18 & 5.2 & 就学 & 6 & 1.4 \\
\hline \multirow[t]{2}{*}{ 生理前に其含が要い } & 非就学 & 10 & 6.3 & 非就労 & 5 & 1.6 \\
\hline & 競労 & 15 & 4.4 & 就学 & 13 & 3.0 \\
\hline \multirow[t]{2}{*}{ 不正出血 } & 非就労 & 11 & 0.9 & 非韩学 & 66 & 21.6 \\
\hline & 就労 & 43 & 12.5 & 歁労 & 83 & 18.9 \\
\hline \multirow[t]{2}{*}{ おしもの-外隘閐逴症状 } & 非就労 & 44 & 27.5 & 非就学 & 87 & 28.4 \\
\hline & 就労 & 75 & 21.9 & 韩労 & 108 & 24.5 \\
\hline \multirow{2}{*}{ 更年期陮害 } & 非就労 & 13 & 8.1 & 非新学 & 24 & 7.8 \\
\hline & 朝労 & 43 & 12.5 & 碀労 & 28 & 6.4 \\
\hline \multirow[t]{2}{*}{ 轧閶のしこり } & 非就労 & 14 & 8.8 & 非就労 & 5 & $t .6$ \\
\hline & 就労 & 17 & 5.0 & 新労 & 6 & 1.4 \\
\hline \multirow[t]{2}{*}{ 捰痛のはり } & 非就労 & 1 & 0.6 & 非就労 & 2 & 0.7 \\
\hline & 就労 & 4 & 1.2 & 桓労 & 2 & 0.5 \\
\hline \multirow[t]{2}{*}{ 赤ちおんができない } & 非就労 & 3 & 1.9 & 非就学 & 28 & 9.2 \\
\hline & 就労 & 24 & 70 & 新労 & 41 & 9.3 \\
\hline \multirow[t]{2}{*}{$\overline{\text { tit }}$} & 非就労 & 160 & & 非㜞学 & 300 & \\
\hline & 敦学 & 343 & & 勃労 & 440 & \\
\hline
\end{tabular}

